\title{
Deleveraging of the Central-Eastern-European Countries' Bank Systems during and after the Economic Crisis
}

\author{
Sándor Bozsik \\ Faculty of Economics, University of Miskolc, Hungary
}

Copyright $\subset 2018$ by authors, all rights reserved. Authors agree that this article remains permanently open access under the terms of the Creative Commons Attribution License 4.0 International License

\begin{abstract}
The economic crisis broke out in the most developed part of the world in 2008 affected seriously to the Central-Eastern-European bank systems. It wasn't a wonder, because these economies were closely linked to the developed countries. Firstly the Central-Eastern-European banks were mostly owned by large Western-European banks, and the management of these subsidiaries became tougher due to the asset management problems of their mother banks (Tressel, 2010). The current paper examines the deleveraging of bank systems of this area during the crisis and thereafter. A special northern-southern division can be observed among the Central-Eastern-European bank systems, where the border is unfortunately at the northern border of Hungary. During the crisis, the amount of private loan was mostly determined by the economic growth, the starting state of loan-deposit ratio, as well as the uncertainty of sovereign CDS spread. In the after-crisis period the change in private loan stock is especially the function of non-performing loan ratio and the change in loan-deposit ratio. Hungary is an 'off-line' country in case of all strong correlated variable pair, so the decrease of private loan may have country-specific reasons besides the general theoretical variables.
\end{abstract}

Keywords Deleverage, Bank System, Central-Eastern Europe

\section{Introduction}

The Central-European economies were more or less influenced by the financial crisis broke out in 2008. The local fragile bank systems were the very first victims of the crisis, since most of the local banks were owned by large Western-European financial institutions. The portfolio deterioration of the mother banks made the management of the local subsidiaries harder. (Tressel, 2010) Since 2011 the local banks weren't supported by the financing sources of their owner, moreover some mother bank began to withdraw deposits from their Eastern-European branches to meet the consolidation requirements prescribed by their home countries. Secondly most of the related country suffered from the consequences of easy or predator lending, the asset quality worsened heavily. Thirdly the sphere of potential debtor decreased due to the economic crisis which followed the financial crisis. The fourth potential reason of decreased outstanding loan was the intervention of state economic policy. The majority of Central-Eastern-European states introduced sectorial taxes on financial institutions and strengthened the supervisory rules by the recommendation of Basel III.

Nevertheless the financial crisis affected the Central-Eastern-European countries in different manners. This study is devoted to explore the explaining factors of the banks' asset deleverage.

\section{Materials}

The deleveraging is related to the capital leverage. The capital leverage refers to the structure of financing, namely the ratio between equity and liabilities. It has got several measurement, in our case the capital leverage means the total assets/shareholders' equity ratio. (Burke, 2015)

Deleveraging means that the enterprises change their leverage in each phases of economic cycle. During recovering and overheating, when the profitability is high and the companies need loan to finance their investments, the leverage increases. During recession, the profitability of companies decrease and their aim is to decrease their fixed revenues costs. Since the interest is such a fixed expense, the companies strive to repay their loans and decrease their leverage due to minimise the interest expenses. 
By a paper published in the Hungarian "Közgazdasági Szemle": "We are talking about deleverage, if the actors of the economy judge due to the changing economic circumstances, that their leverage is exaggerated, and they make their economic decisions to build down their debt readjusting their asset structure, so the deleverage is a synonym of debt repayment." (Kiss - Szilágyi, 2014; page 955) By the authors, the deleveraging process proceeds the following pattern in case of banks: The erupting financial crisis (huge amount of bad loan) increases the leverage of banks, since the losses can be written off from the equity. Since the capital increase has got severe limitation during the circumstances of a crisis(no profit, high aversion against risky investments), the leverage can be restated only by decreasing the outstanding and loans.

In micro level the deleverage means, that the enterprises are forced to decrease their expenses due to the fall of their incomes, thus they minimise their debt level, to decrease the interest expenses. Secondly their working capital needs are decreasing due to the fallen sales, their investment opportunities are worsening, which decreases their both long and short-term loan demand.

In macro level the banks withdraw their outstanding. The stock of non-performing loan is increasing, which decreases the equity of banks. The lowering equity level forces the banks to decrease the lending to meet the capital adequacy directives. Secondly the risk bearing ability of banks lowers since the deteriorating asset quality, so they turn to the less risky investments (like state securities) against the more risky bank (De Bondt, 2002).

The above procyclical behaviour of banks was one of the most important learning from the economic crisis started in 2007 (Kovács, 2014). Whereas the monetary authorities and the governments strived to increase the aggregate demand through deficit increase and lower prime rate, the behaviour of financial sector deepened the crisis. The bank system began a credit crunch answering to the worsening quality of outstanding and disappearing liquidity in financial markets, and by that it decreased the aggregate demand.

Before the financial crisis the behaviour of bank systems was the opposite. The financial institutions increased the volume of outstanding disregarding the beard risk, which (especially in the real estate market) leaded to create asset price bubbles. (Kovács, 2014)

Let's look, how the lending boom leads theoretically to create asset price bubbles and how the bursting of bubbles leads to withdraw the banks' lending activity! (Acharya-Naqvi, 2011)

The assumptions of this model are the followings (see the chart below):

The riskier is an investment idea, the higher the interest rate of loan - line "a".

The higher is the lending rate, the lower quantity of investments is made - line " $\mathrm{b}$ ".
The lower is the quantity of investments, the lower is the price of invested assets - line "c".

The bigger is the risk of an asset, the lower is its price line "d".

Let's look the following chart for the explanation! The solid line of this chart represents the equilibrium among the asset price (real estate price), the risk, the interest rate and the level of investments.

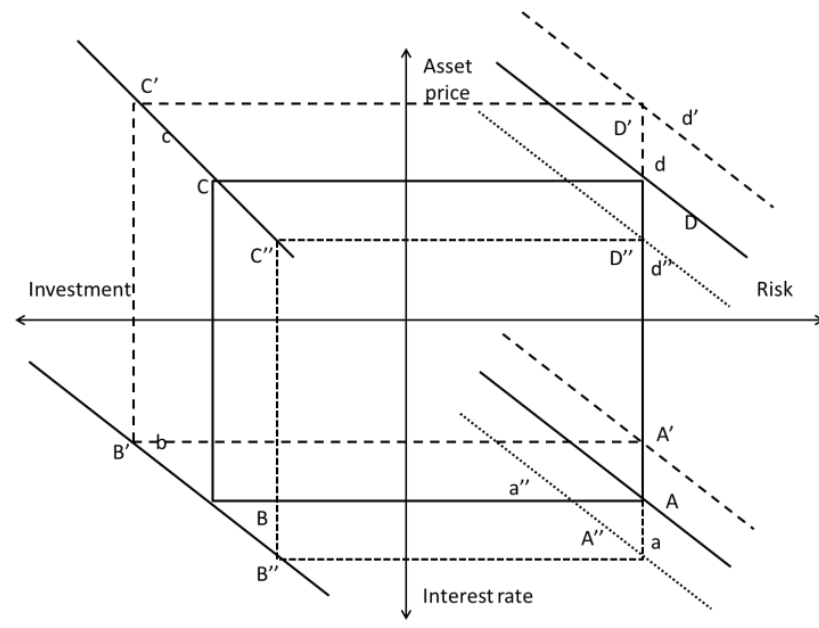

Source: Acahrya-Naqvi, 2011

Chart 1. Creation of asset bubbles

Now let's look, how the asset bubbles are created! The banks underestimate the expected risk of their loans, and therefore line "a" shifts to right-up, and the lending rate falls (from $A$ to $A^{\prime}$ ), and they give more loan for investments, so the size of investment increases from B to B'. The increasing demand beats up the asset prices, so the risky assets become overvalued, the price-risk axis shifts from line "d" to line "d". The asset bubble is established denoted by the dotted square.

The busted asset bubble leads the prices down from D' to D'. The decreasing prices throw back the demand for investment from C' to C', the worsening loan portfolio leads to higher real loan rates from B' to B'. The risk aversion of banks increases, so they finance the same risk for higher lending rate (from A' to A').

Consequently the risk bearing attitude of banks is high during overheating, the real lending rates are low, which leads to increasing investments and increasing asset prices.

During recession the process is precisely reversed. The higher risk version leads to decreasing prices, decreasing investments and high real rates.

The process is self-generating in both ways. The human psychology stands behind both by the behavioural finance theory. During overheating the exaggerated self-confidence rules as during recession the panic explains the human behaviour. (De Bondt, 2012).

Takács's and Upper's study deals with the sensitivity of banks' loan stock to the economic cycles. (Takáts-Upper, 2013) They examined 39 economic crises, where the creation of the bubbles advanced the abruption of the crisis. 
They found, that the recovery from the crisis doesn't hinder the deleveraging (the decrease of lending). They haven't found any correlation between the two years economic growth after the crisis and the change in loan stock/GDP ratio. The economic recovery depends on the indebtedness of the country and the real rate of interest by their examination.

The deleveraging is natural in economic recession. However it is not irrelevant, what is its size and by considering this the literature differentiate "good" and "bad" deleverage. (Bologna et al., 2014) In case of good deleverage the bank just simply adjust to the changing economic circumstances to avoid the bankruptcy. Thus as the loan request of potential debtors decreases, the bank repays its especially external, foreign sources, so its capital adequacy improves, however its profitability decreases. However the bank made its credit terms stringent to crowd out the risky debtors from the lending, but it remains available for the solvent debtors.

We are talking about bad deleverage, if the fall in loan stock is the consequence of rising bad loan stock. In this case the fall of loan stock doesn't improve the capital adequacy since the lowering equity base caused by the loss from bad lending. Thus the bank is forced to withdraw dramatically its outstanding to meet the regulatory directives, even if it refuses the lending of its good customers. This phenomenon is often called - credit crunch. The credit crunch deepens further the recession and consequently worsens further the level of bad loans. An evil circle can be established, which can be solved only by the state (through consolidating the bank through purchasing the banks' bad loans). However if the state's solvency is also weak, only the international financial institutions can help.

Paradoxically the credit crunch originating in the USA caused the largest recession and deleverage in Europe. This has got basically two reasons:

The first is, that the European banks suffered meaningful losses in their direct and indirect American investments.
The fertilisation effects were examined by one of the IMF study. (Cerutti - Claessens, 2014) It stated, that the supply side factors (namely the factors depending from banks) played bigger role in deleverage, than the decrease of loan demand. The banks strengthened their credit terms due to the fertilisation effect. If the bank or its mother bank made a lot of losses in the American outstanding, then the bank held in (or forced to hold in) it's outstanding in the home market. The fertilisation effect was deepened by the bank's dependency from external sources, since he crisis froze the operation of interbank financial markets - causing a liquidity crisis for banks with high loan/deposit ratio.

This fertilisation effect is enhanced by the Worldbank's expert, when they analysed the deleverage of Central-Eastern European banks. (Feyen et al., 2014) The larger was the dependency of these banks from external sources, the bigger was the deleverage to repay these external sources. The share of foreign equity didn't play any explaining role in deleverage, so it didn't matter, if the bank was in foreign or in domestic hands, the banks decreased the lending if the loans were finances from foreign sources.

The second reason was that in some countries problems emerged related to the sovereign debt (PIGS countries, Hungary). Since they didn't receive financing sources from the markets, they were forced to turn to international institutions, which linked their loan to meaningful austerity instructions. So these states couldn't help to recover their economy, but the economic policy further deepened the crisis. Naturally the problems with sovereign debt related disadvantageously to the financing cost of the domestic banks, thus the deleveraging was extremely serious in those countries, where there were problems with the state debt. (Vause et al, 2012)

The mechanism of European economic crisis and the deleverage is described by the following chart (BornhorstArranz, 2013). 


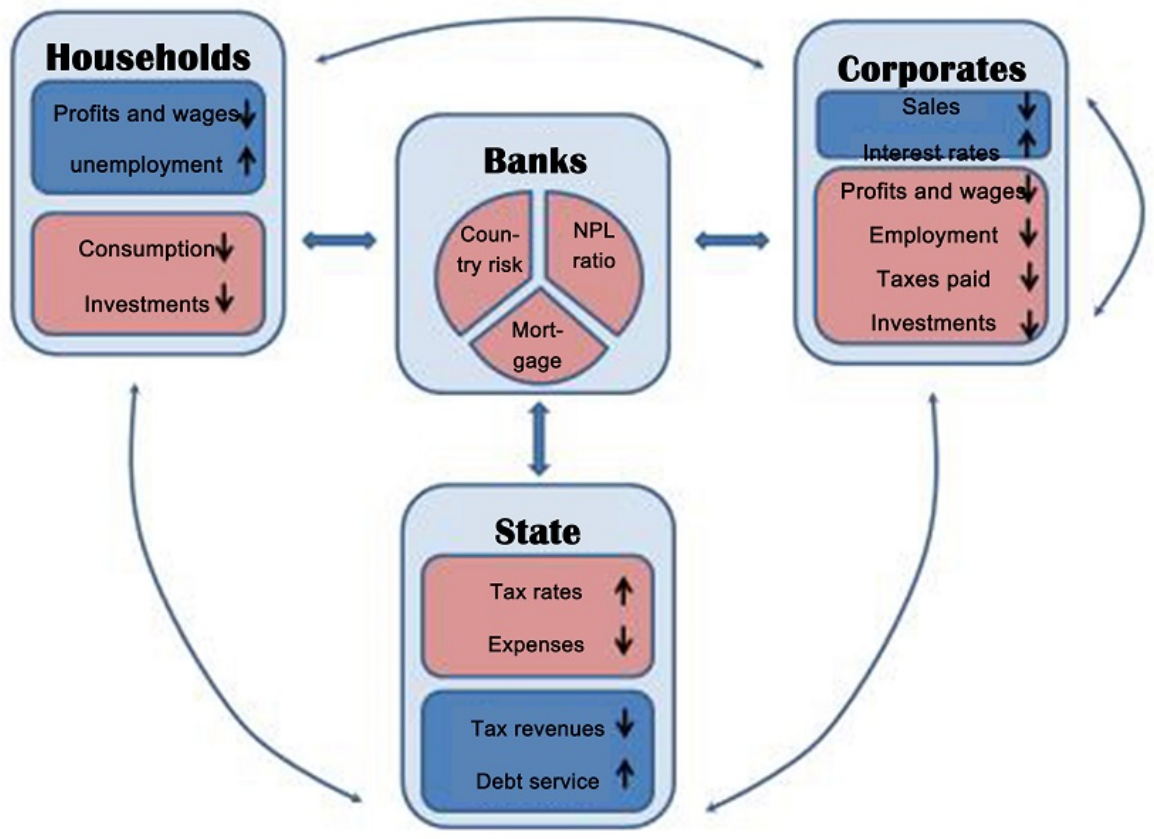

Source: Bornhorst-Arranz, 2013

Chart 2. Linkage between deleverages

The above chart shows the evil circle of recession. The bursting of mortgage market bubble decreases the value of mortgage, which forces the bank to withdraw loans in every overdebted sectors. The decrease of lending decreases the residential investments and also decreases the income of companies producing commodities (especially the income of building industry and car industry). These companies decline their production, which leads to cost reduction programs, firing the staff and lower level of investments. This decreases the income of the households, which leads a further decrease of the aggregate demand. The widespread recession is perceived by the banks, because their loan portfolio worsens further. The lending losses and the emerging risk force them to make their credit terms more severe, which effects negatively to the declining residential and commercial investments.

The above situation is more serious, if the state was heavily indebted before the crisis. The recession decreases the state's revenue, and its expenses increase to soften the social effect of recession. However the larger deficit is not an option due to the lack of finance. So the state increases taxes and decreases the public spending and sells the public property (privatisation) at a very low price (deep in recession). This deepens further the crisis.

The linkage between the sovereign debt rating of Central-Eastern-European countries and the bank deleveraging appears in the study of Benczúr and Kónya (Benczúr-Kónya, 2015). By this paper the bigger was the increase of sovereign debt CDS spreads, the larger was the drop in foreign deposits during the crisis.

The private loan stock significantly decreased in the countries of European Union during the crisis (Schoenmaker-Peek, 2014). This decline was especially meaningful in the peripheral countries (in East- and South-Europe, as well as in Ireland). By examining the countries' banks, they stated that the private loan stock decline was larger in case of banks consolidated by the states, than in case of banks with normal capital adequacy. The deleveraging was especially the consequence of lowering equity level, which forced the bank to decrease the lending to meet the strengthening bank regulation.

The deleveraging was examined by one of the World Bank's study from the aspect of tightening credit terms. (Feyen et al., 2012) It stated, that the banks operating in emerging markets (especially in Eastern-Europe) tightened their credit terms due to the crisis, however the capital adequacy (thanks to the mother banks' support) is here the highest. So the decrease of private loan stock wasn't caused by the lack of capital, but the other indicators of economic situation (recession, high level of non-performing loans, the cash-flow hunger of mother banks and the high loan to deposit ratio).

Finally a comprehensive study of VOXEDU listed the triggering factors of deleverage in the European Union (Feyen et al., 2013). The study differentiates three factor-groups of European deleverage - these are the financial, regulational and economic political factors.

The study overviews the market conditions on financial 
factors. The tightening inter-bank market conditions, the worsening rating of debtors, the problems of foreign currency nominated loans, withdrawal of foreign sources were listed. Similar statements can be found in Gróf's study. (Gróf, 2016)

The regulational factors relates to the gradual introduction of the new Basel-III agreement. The capital adequacy requirements are tightening and encouraging the banks to follow less procyclical behaviour. New aspect is the recognition of liquidity risk and the new liquidity indicators. These strive the banks to limit the outstanding in medium term.

The study mentions among the economic political reasons that the economic recession linked with austerity packages in several countries facing with high public debt (tax raise, public expense cut). This deepens the recession and decreases the number of lendable private debtors. The recession limits the income-generating ability of banks and hinders the quick write-off of bad loans.

After surveying the theoretical models this paper examines, what is the explanation power of factors by the empirical data of the Central-Eastern-European countries, and how their relevance changed after the crisis considering the private loan stock?

\section{Methods}

The aim of current paper is to examine the deleverage in the Eastern part of European Union (among the former socialist countries). Firstly I examine, how the deleverage related the Central-Eastern-European countries and how quick is the recovery since 2013 by the newest available statistics.

Secondly I separated which country's bank system was characterised by "good" or "bad" deleveraging. Due to the lack of data, the examines were made on the whole bank system of the countries rather than on individual banks based on the data of Worldbank, European Central Bank and the European Statistical Office.

After separating the "bad" and "good" deleverage I surveyed, if there are any sign of private debt increase after the deepest point of the crisis (since 2012), and how the influencing factors of deleverage behaviour during that period.

The annual change in corporate and household loan was considered as the indicator of deleverage. This was the dependent variable. So the total outstanding of bank sector was decreased by the amount of public loan and the amount of foreign loan. The reason of this is that the primary goal of public lending is not to earn profit, but to ensure the required liquidity and capital adequacy. That's why the public outstanding (which means mainly the purchase of government securities) doesn't react to the shape of economic cycle in the same way, as the private outstanding.

The foreign loans - considering the fact, that the examined region is poor in capital - are not typical outstanding of the region's banks, and here we cannot separate, that the foreign income holder is private or public, which was crucial in this analysis.

By the references I judge to examine the role of four factors in case of Central-Eastern European bank systems. These are the followings:

- $\quad$ Fertilise effect from developed (Western-European) bank systems

- $\quad$ Non-performing loan stock

- Current state of economic cycle

- Country risk

Four explaining variables were created to separate these four factors.

The fertilise effect is strong in a given state, if the foreign liabilities had got significant stake in the total bank's liabilities. If the mother bank went to trouble, it tried to get more cash inflow, so tried to reclaim its foreign outstanding. In several cases the consolidation contracts made between the mother bank and its state also prescribed the liquidation of foreign investments. Due to the lack of proper data I approached the exposure of liabilities from mother bank with the corporate and household loan to deposit ratio at the end of 2008. Before the crisis the banks of the examined region took significant foreign liabilities to finance the lending boom, and their loan to deposit ratio significantly increased.

\section{H1: I suppose, that the higher was the loan to deposit ratio, the bigger was the extent of private loan decrease during the crisis.}

The decreasing quality of loan portfolio was measured by the change of non-performing loan percentage between 2008 and 2012. Generally the quality of loan portfolio was the worst in 2012 in the examined country group.

\section{H2: I suppose, that the bigger was the quality decrease of loan portfolio, the greater was the fall in private outstanding.}

The depth of economic crisis may have significant effect to the size of private loan, because the base of potential solvent customers was decreasing. In recession the good managed company keeps its working capital level low, doesn't make any unnecessarily investments, and so it's financing needs was decreasing. The size of economic crisis was measured by the difference between the 2008 and 2012 real GDP. I chose this long period, because the economic crisis followed a "W" shape in most of the countries, with two recession depths (in 2009 and in 2012). The recovery started since 2013 .

\section{H3: I suppose, that the larger was the fall in GDP, the bigger was the deleverage.}

The uncertainty of country risk was measured by the 
standard deviation of sovereign debt of the related country between the end of 2007 and 2012 .

\section{H4: I suppose, that the bigger was the volatility of CDS spread, the bigger was the decrease in private loan stock.}

The examined countries can be found in the Eastern part of the European Union, who joined to the Union after 2004. (Bulgaria, Romania, Hungary, Slovakia, Czech Republic, Poland, Slovenia, Croatia and the three Baltic states Lithuania, Estonia and Latvia). The data came from three sources. The GDP was downloaded from the Eurostat's website, the non-performing loan ratio came from the Worldbank's database and the source of loan and deposit stock was the database of European Central Bank. The historical CDS spreads are available at the website of DataGrapple.

In case of Croatia and Latvia the ECB database doesn't contain any data, in case of Slovenia the CDS spreads aren't available.

The statistical analysis was made by SPSS 22.0.

Due to the lack of data I hade 8-11 cases, so I used scatter plot to expose the linkage between each of the independent variables and the dependent variable. The stronger is the linkage, the better fits the plots in a line or curve. The research was made both the during-crisis and the post-crisis periods.

\section{Results}

Firstly I represented the size of deleverage, by using a scatter plot chart where the horizontal axis demonstrated the change in private loan during the crisis, and the vertical axis presented the post-crisis change of private debt. The farer is a country from the left lower corner of the chart, the smaller was the degree of deleverage (or even there was a leverage.) By the distance from the left lower corner I ranked the countries in a descending order.

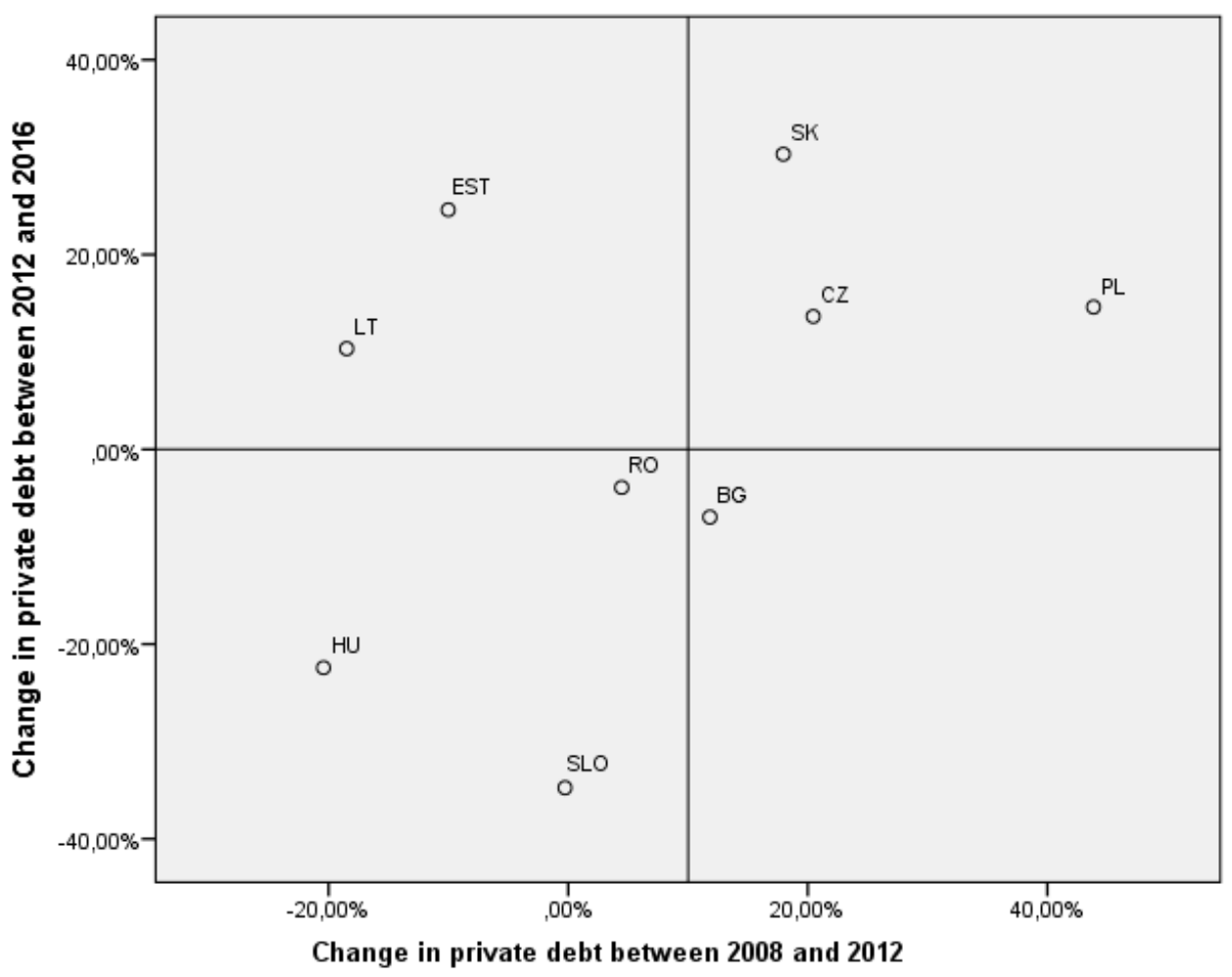

Source: ECB, own work

Chart 3. Change of private debt during and after the crisis 
From the chart it can be seen, that the largest fall of private debt was suffered by Hungary both during and after the crisis. The decrease was $20 \%-20 \%$ in euro term in both cases. Slovenia shows almost similar wrong case, but the drop of lending happened not during but after the crisis. Romania and Bulgaria indicate a stagnation in private lending in both periods in euro terms. The Baltic States showed a strong recovery after the crisis followed by a big drop during the recession. In Slovakia, in Czech Republic and in Poland the size of private lending didn't reflect the crisis, both periods brought significant increase in private lending. Based on this result I made the following clusters related to the deleveraging (based on the distance from the left lower corner).

Poland, Slovakia, Czech Republic - dynamic increase Estonia, Latvia, Lithuania - strong exposure to the crisis
Bulgaria, Romania - stagnation

Croatia, Slovenia, Hungary - decaying outstanding

Lithuania and Croatia were ranked by available data since 2010 that was indicated by italics.

To examine the private loan stock we can notice a characteristic north-south division. The northern part of countries quickly recovered from the shock of crisis, or even the recession hadn't got any effect on private lending. The southern (generally poorer) part showed a stagnation or in case of West-Balkan countries (in that aspect Hungary was ordered here) the fall of private lending remained after the crisis. The biggest deleverage was however in Hungary.

In the Central-Eastern European countries the linkage between the private lending and the GDP during and after the crisis is shown by the following charts.
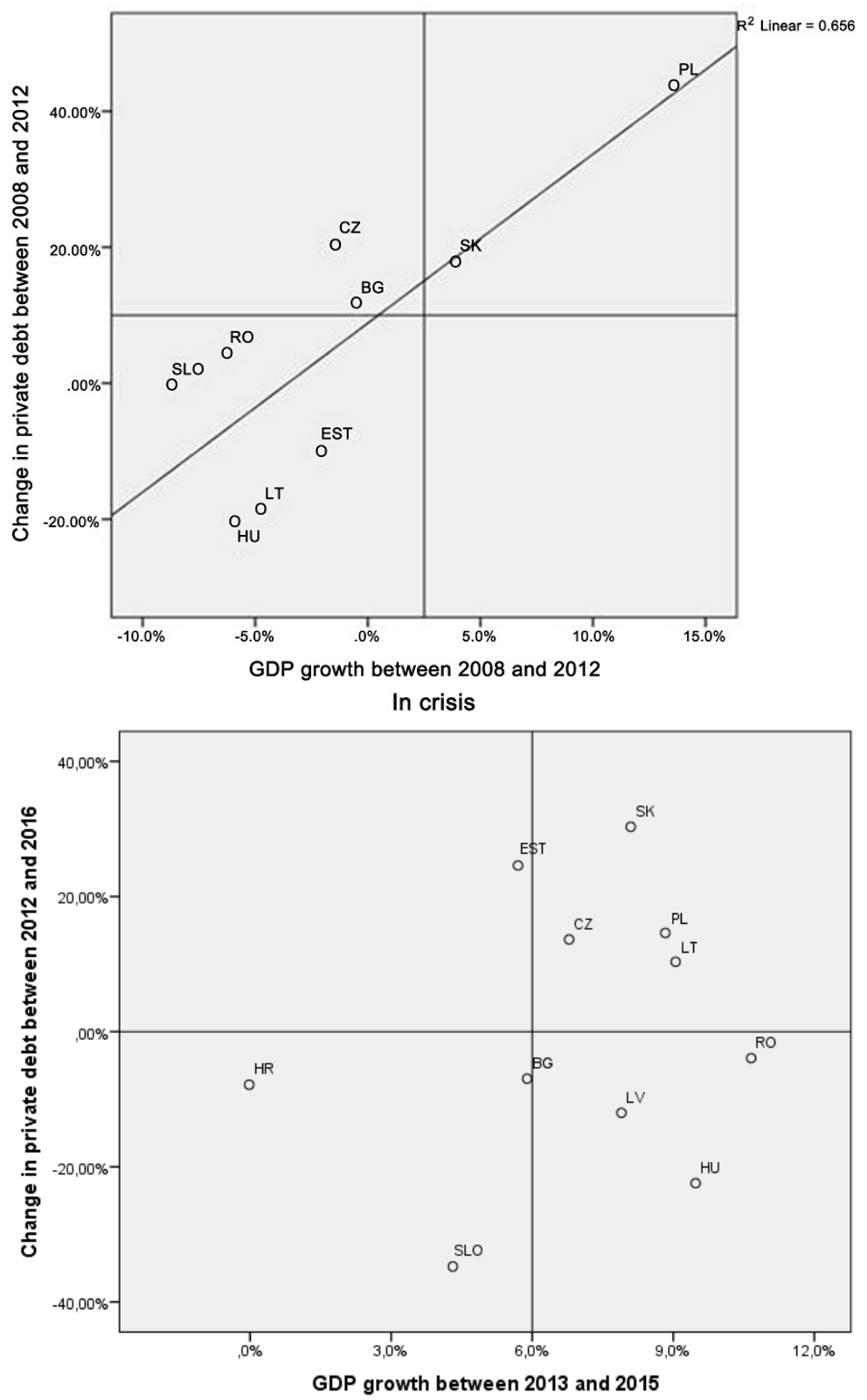

Source: ECB, own work

Chart 4. and 5. Linkage between private lending and GDP 
It can be seen, that during the crisis the deleverage is clearly explained by the change in GDP. The larger is the fall in GDP, the more significant is the drop in private lending. However the Baltic States and Hungary suffered bigger drop in lending, than the GDP decline. In the "above the line" countries (Slovenia, Romania and the Czech Republic) the drop of private lending was not as big as the fall in GDP.

However the GDP doesn't explain so clearly the situation after the crisis. Between 2013 and 2015 Romania and Hungary earned the biggest growth, but the lending deteriorated further. The countries with expanding private debt didn't make significant better economic growth.

The explanation of this phenomenon can be the "bad" deleveraging. If the bank system has got too many bad loans, the increase of private lending postponed due to the high perceived risk.
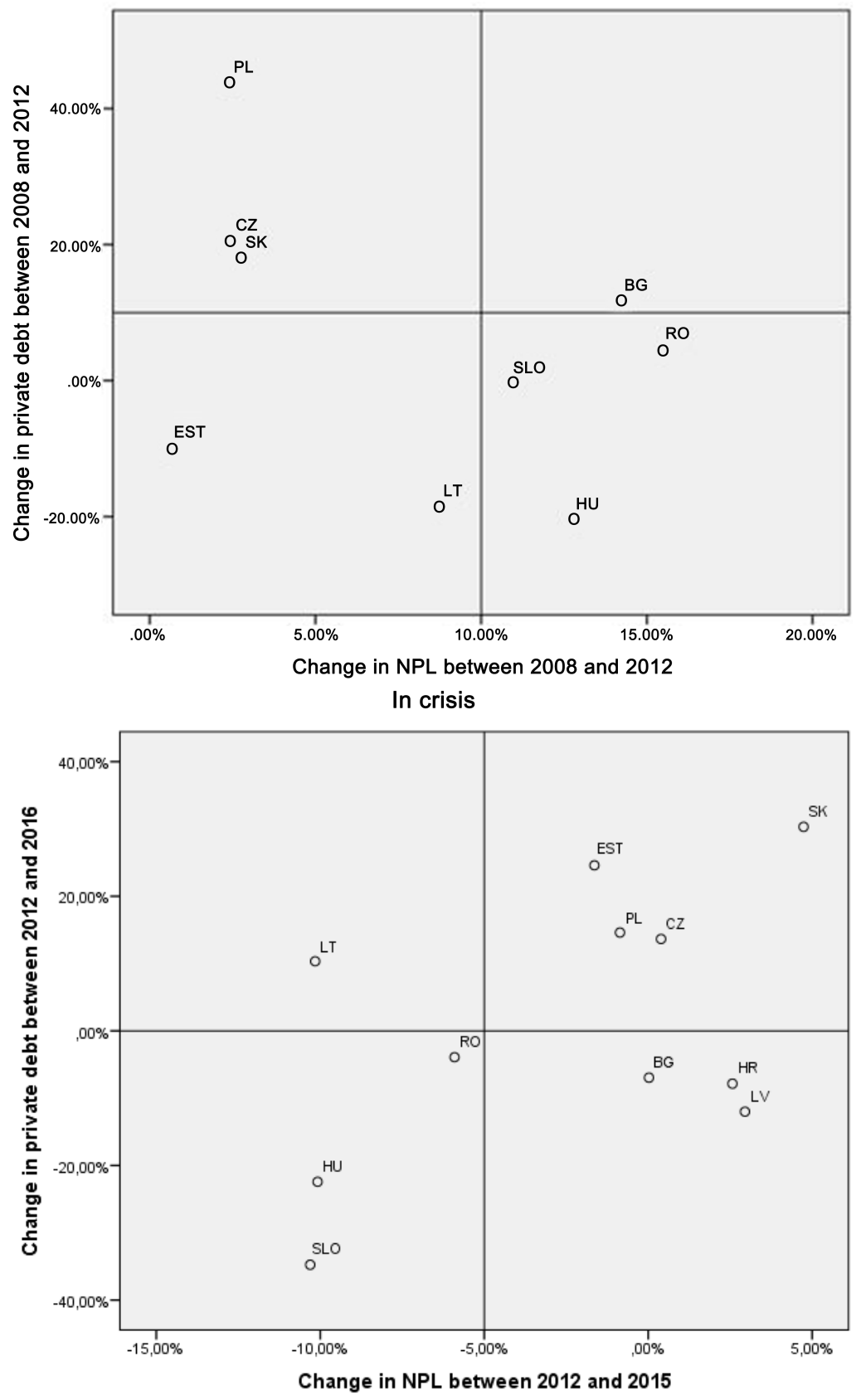

Source: ECB, Worldbank, own work

Chart 6. and 7. Linkage of private loan and bad loan 
The bad loan ratio explained the deleverage better in the post-crisis period than during the crisis against the GDP change. After the crisis, the biggest drop of the loan quality had happened in Slovenia and in Hungary and the deleveraging was the most significant in these countries. Croatia, Lithuania and Bulgaria are far from the regression line, as in the opposite case Latvia and Estonia.

The differences may come from the various change of loan to deposit ratio. After the crisis the banks strive to bring their loan to deposit ratio close to 1 , since the inter-bank money market was frozen, and some regional bank couldn't expect help from its mother bank. The explaining power of loan to deposit ratio remains after the crisis. During the crisis I used the opening balance of loan-to-deposit ratio, while in the post-crisis period I used the change of loan-to-deposit ratio. After the crisis, the lack of domestic deposit can constrain the increase of private lending.
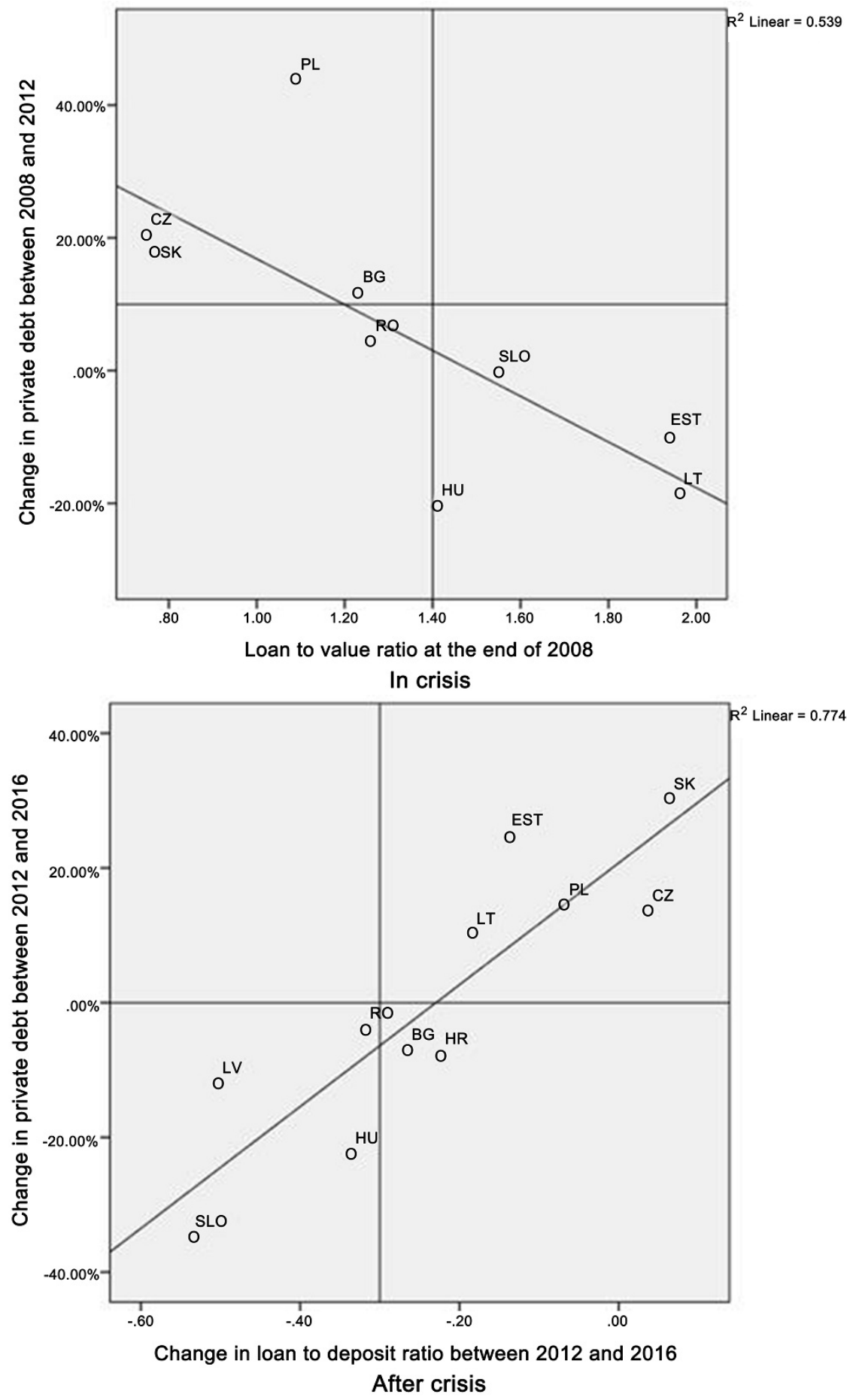

Source: ECB, own work

Chart 8. and 9. Linkage between the private lending and the loan-to-deposit ratio 
It can be seen, that the dependence from domestic deposits explains well the change in private lending. In 2008 the private loan stock significantly decreased in the net lending countries. Where the bank system has got significant domestic deposit base (Visegradian countries except of Hungary) - the amount of private lending increased against the crisis. However Hungary is an "under-line" country, the loan stock decreased more, than it could be explained by the loan-to-deposit ratio.

After the crisis, the loans increase if the deposits increase and vice versa. If the deposits decrease, the lending decreases regardless to the state of economy.

Finally let's look the effect of sovereign debt risk to the stock of Central-Eastern European private loan stock. The sovereign risk is considered to be zero in case of Estonia while its public indebtedness is extremely low and there is no listed CDS spread on Estonian public debt.

From the chart below, it can be seen, that the uncertainty of sovereign risk spread affects the level of private debt. The linkage is reversed. The larger is the uncertainty of CDS spread, the bigger is the deleverage. However the slope of line is steeper after crisis, so the importance of sovereign debt uncertainty is bigger in the post-crisis period than before.

Important to note, that there is a strong linkage between the non-performing loan ratio and the risk of sovereign debt ranking. I have prepared the correlation matrix of the available independent variables, and I've found a not significant but medium strong correlation (0.8) between these two variables during the crisis. In the post crisis period this linkage disappeared.

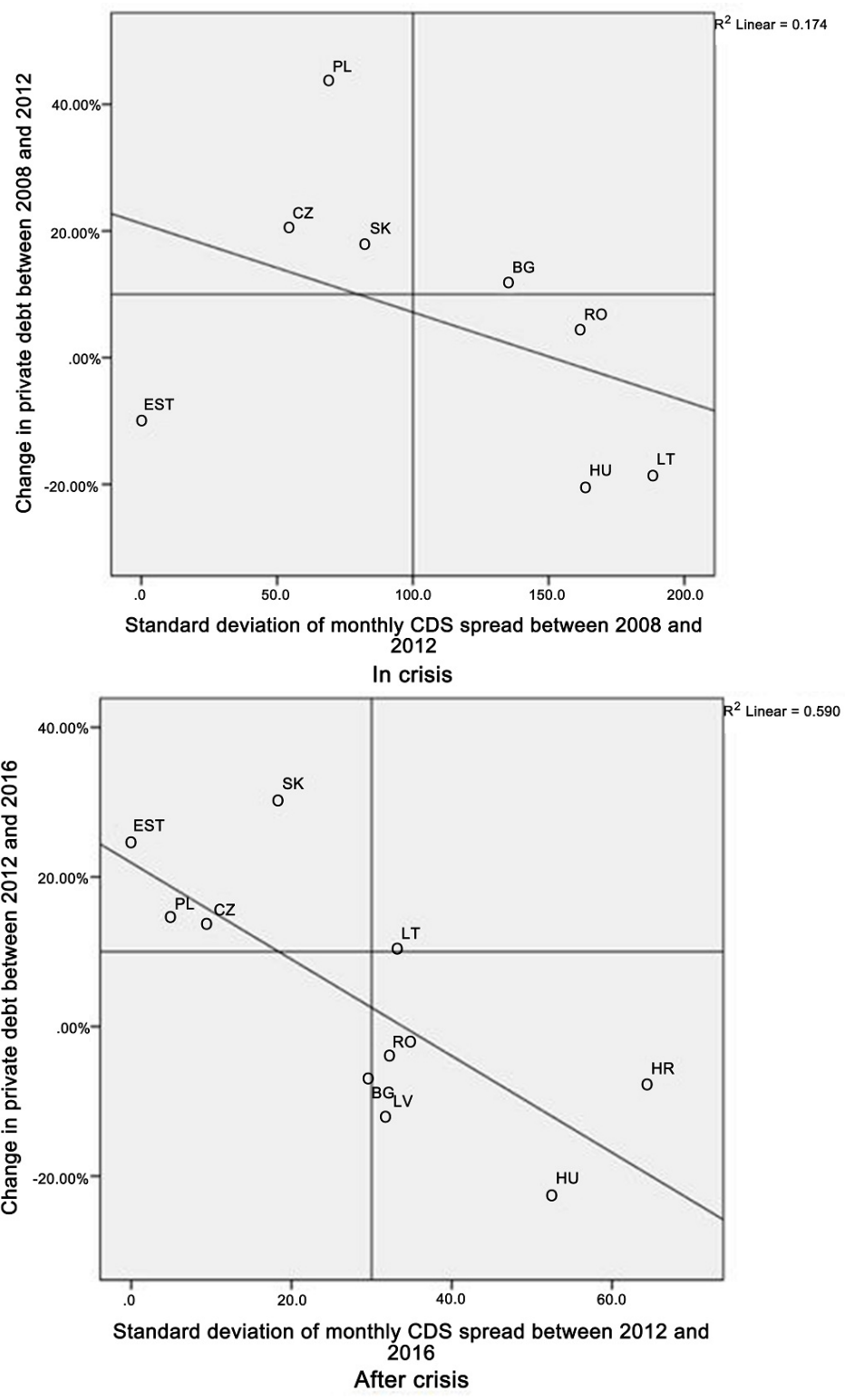

Source: ECB, DataGrapple, own work

Chart 10-11. Linkage between private debt and standard deviation of CDS spread 


\section{Discussions}

Theses H1 is fully accepted, $\mathrm{H} 2$ proved relevant only in the after crisis period, $\mathrm{H} 3$ seems to be valid only during the crisis, while the examination supports $\mathrm{H} 4$ only in the after crisis period.

The following consequences can be drawn from studying the charts and data:

A characteristic northern-southern division can be observed in the deleverage of Central-Eastern European countries, where the border line is at the northern part of Hungary. In the northern part of the region the increase of private loan was continuous, as in the Visegrad-group (expect of Hungary), or a rapid fall in the crisis was followed by a similarly rapid rebuilding of private debt (except of Lithuania). The Southern part of the region suffered heavy loss in private lending in the crisis and there is no sign of recovery up to 2016 in euro terms. The mostly affected country is Hungary.

The change in private debt was determined by the GDP, the opening level of loan-to-deposit ratio, and respectively the uncertainty of sovereign debt rating. However in the post crisis period the bad loan ratio has got significant explaining power instead of GDP. The northern countries are good examples on "good" deleverage, the Balkan countries have "bad" deleverage. The loan-to-deposit ratio also good indicator for the Southern countries, so the Balkan States suffered not only from bad debt, but also from lowering domestic deposits.

Hungary is an "under-line" country in case of each explaining variables. This can be the consequence of two factors. Firstly the Hungarian bank system has got an accumulated drawback situation, all of the bank specific explaining factor (loan-to-deposit ratio, GDP growth, non-performing loan, and risk of sovereign debt) has got wrong figures during and after the crisis. The only exception was the post-crisis economic growth, where the performance of Hungary was fairly good between 2013 and 2015. The second reason may be, that the Hungarian bank sector was burdened by several special levy (sectorial bank tax introduced firstly in the region with heavy tax rates, consolidation of foreign currency nominated mortgage loans, transaction tax, etc.) These levies limited the profit generating ability of Hungarian banks and also limited the quick write-off of accumulated bad loans.

\section{REFERENCES}

[1] Acharya Viral. - Naqvi Hassan. (2011): Bank Liquidity and Bubbles: Why central banks should lean against liquidity. Loyola University conference on Bubbles and Macroprudential Regulation (2011 április)

[2] Angelides Peter et al. (2011): Final Report of the National Commission on the Causes of the Financial and Economic
Crisis in the United States

http://fcic.law.stanford.edu/report/

[3] Bank of England (2012): Funding for Lending Scheme

[4] BENCZÚR péter - KÓNYA István (2015): Interest Premium, Sudden Stop, and Adjustment in a Small Open Economy Magyar Tudományos Akadémia Közgazdaság- és Regionális Kutatóközpont Mühelytanulmányok MT-DP 2015/5 2015 január, ISBN: 978-615-5447-63-1

[5] Bologna et al (2014): EU Bank deleveraging Questioni di Economia e Finanza 2014 september No 235

[6] Bornhorst Fabian - Arranz Marta Ruiz (2013): The perils of private-sector deleveraging in the Eurozone 2013. november 13.

http://voxeu.org/article/private-deleveraging-eurozone

[7] Burke John Vincent (2015): Assessing bank leverage through flows: an early warning tool of risk-taking.

[8] CERUTTI EugeniO - CLAESSENS Stijn, (2014): The Great Cross-Border Bank Deleveraging: Supply Constraints and Intra-Group Frictions IMF Working Paper 2014/180 2014. szeptember p. 24

[9] DataGrapple database: https://www.datagrapple.com/

[10] DE BONDT Werner (2002): Bubble Psychology University of Wisconsin, Madison

[11] European Central Bank Statistical Data Warehouse http://sdw.ecb.europa.eu/

[12] Eurostat Database http://ec.europa.eu/eurostat/data/database

[13] Feyen Erik - del Mazo Ines Gonzalez, (2013): European bank deleveraging and global credit conditions 2013. május 12

http://voxeu.org/article/european-bank-deleveraging-and-gl obal-credit-conditions

[14] FEYEN Erik - KIBUUKA Katie - ÖTKER-ROBE Inci, (2012): European Bank Deleveraging: Implications for Emerging Market Countries Economic Premise 2012 április No 79 p. 7

[15] FEYEN Erik - LETLIER Raquel - LOVE Inessa MAIMBO Samuel Munzele - ROCHA Roberto, (2014): The Impact of Funding Models and Foreign Bank Ownership on Bank Credit Growth Is Central and Eastern Europe Different? World Bank Policy Research Working Paper 6783, February 2014 p. 57

[16] GRÓF Pál, (2016): Gazdasági válság és szigorodó szabályozás: Változások a magyar bankszektor likviditásmenedzsmentjében 2007 és 2014 között Pénzügy-Számvitel-Statisztika Füzetek 2015 ISBN: 978-615-5216-96-1 Miskolci Egyetemi Kiadó 2016 page $32-431$

[17] http://fac.comtech.depaul.edu/wdebondt/Publications/Bubbl e.pdf

[18] KISS Áron - SZILÁGYI Katalin, (2014): Miért más ez a válság, mint a többi? Közgazdasági szemle, LXI. évf., 2014. September (949-974. o.)

[19] KOVÁCS Levente (2011): A magyar bankrendszer helyzete és kihivásai, Magyar Pénzügyi Almanach 2011-2012, XXI. Volume, pp. 90-96., ISSN 2063-188X 
[20] KOVÁCS Levente (2014): Hitelintézeti konszolidáció és adóskonszolidáció, Magyar Pénzügyi Almanach 2014-2015, XXIV. volume, pp. 62-67., ISSN 2063-188X

[21] SCHOENMAKER Dirk - PEEK Toon (2014): The State of the Banking Sector in Europe OECD Economics Department Working Papers, No. 1102, OECD Publishing. http://dx.doi.org/10.1787/5k3ttg7n4r32-en p. 36

[22] TAKÁTS Előd - UPPER Christian (2013): Credit and growth after financial crises BIS Working Papers 2013 július No. 416 ISBN 1682-7678 p. 28

[23] TRESSEL Thierry (2010): Financial Contagion through Bank Deleveraging: Stylized Facts and Simulations Applied to the Financial Crisis IMF Working Paper 10/236 p.38.

[24] VAUSE Nick - VON PETER Goetz, DREHMAN Matthias, SUSHKO Vladyslav: European bank funding and deleveraging BIS Quarterly Review, 2012. March p. 12

[25] Word Bank Database

http://data.worldbank.org/indicator/FR.INR.LEND 